SEHATI

Jurnal Kesehatan
Vol 1, No 2, Agustus 2021, p. 47-56

e-ISSN : 2775-6963 | p-ISSN : 2775-6955

DOI: https://doi.org/10.52364/sehati.v1i2.6

RESEARCH ARTICLE

OPEN ACCESS

\title{
Pengaruh lingkungan kerja fisik dan lingkungan kerja non fisik terhadap tindakan keselamatan dan kesehatan kerja (K3) di PT. Mitra Bumi
}

\author{
Vivi Indriani ${ }^{1}$, Yusni Ikhwan Siregar ${ }^{2}$, Syahril $^{3}$ \\ ${ }^{1}$ Mahasiswa Program Studi Magister Ilmu Lingkungan Program Pascasarjana Universitas Riau \\ ${ }^{2}$ Dosen Program Studi Magister Ilmu Lingkungan Program Pascasarjana Universitas Riau \\ ${ }^{3}$ Dosen Pendidikan Fisika FKIP Universitas Riau \\ *Correspondent Email: vivibkn29@gmail.com \\ Diterima: 07 Mei 2021 | Disetujui: 30 Agustus 2021 | Diterbitkan: 31 Agustus 2021
}

\begin{abstract}
Occupational Safety and Health (OSH) is one of the protection measures aimed at all potentials that can cause danger, so that workers and other people in the workplace are always safe and healthy and all production sources can be used safely and efficiently. The purpose of this study is to determine the relationship between physical work environment (lighting, temperature, noise and humidity) and non-physical (knowledge of workers, behavior based safety, availability of tools and company regulations) to occupational safety and health (OSH) measures and to determine the most important factors. dominant in the physical work environment and non-physical work environment to the Occupational Safety and Health (OSH) action at PT. Mitra Bumi. This research was conducted at PT. Mitra Bumi in January-March 2020. This type of research is a quantitative study with a cross sectional study approach. The results showed that there is a relationship between the physical work environment (lighting, temperature, noise and humidity) to the Occupational Health and Safety (OSH) measures at PT. Mitra Bumi. There is no relationship between the non-physical work environment (workers' knowledge, behavior based safety, availability of company tools and regulations) to Occupational Safety and Health (OSH) actions at PT. Mitra Bumi. The most dominant factor on the action of Occupational Safety and Health (OSH) at PT. Mitra Bumi is a physical work environment, namely lighting and noise.
\end{abstract}

Keywords: Physical Work Environment, Non-Physical Work Environment, Occupational Safety, Health (OSH)

Keselamatan dan Kesehatan Kerja (K3) merupakan salah satu upaya perlindungan yang ditujukan kepada semua potensi yang dapat menimbulkan bahaya, agar tenaga kerja dan orang lain yang ada di tempat kerja selalu dalam keadaan selamat dan sehat serta semua sumber produksi dapat digunakan secara aman dan efisien. K3 harus benar-benar diterapkan dalam suatu perusahaan, pengawasan tidak hanya terhadap mesin saja tetapi yang lebih penting terhadap manusianya. Hal ini dilakukan karena manusia adalah faktor yang paling penting dalam suatu proses produksi (Endroyo, 2006).

Jumlah kasus kecelakaan akibat kerja Tahun 2015-2018 yang paling tinggi ada pada Tahun 2017 yaitu 35.917 kasus kecelakaan kerja. Dimana pada Tahun 2015 yaitu 9.891 kasus, Tahun 2016 yaitu 21.735 kasus dan Tahun 2018 yaitu 24.910 kasus. Provinsi dengan jumlah kecelakaan akibat kerja tertinggi pada Tahun 2018 adalah Provinsi Sulawesi Selatan, Riau dan Bali (Infodatin Kemenkes RI, 2019). Setiap tahun ditargetkan angka kecelakaan kerja 50\% lebih sedikit dibanding tahun sebelumnya. Dampak kecelakaan pada perusahaan salah satunya adalah kelambatan produksi. Padahal ketepatan waktu dapat menghemat biaya yang besar. Oleh karena itu penerapan K3 sangatlah penting selain untuk mencegah kecelakaan, penerapan K3 dapat meningkatkan keandalan perusahaan, sehingga dapat menimbulkan kepercayaan kepada pelanggan dan konsumen (Ardani, 2013).

Adanya K3 pada dasarnya bertujuan untuk mencegah dan mengurangi terjadinya kecelakaan dan penyakit akibat kerja, untuk mewujudkan tujuan tersebut maka di setiap tempat kerja diwajibkan memenuhi syarat K3 yang ditetapkan dalam Undang-Undang nomor 1 Tahun 1970 beserta peraturan pelaksanaannya. Pengupayaan perlindungan tenaga kerja berupa APD pada hakikatnya merupakan upaya meningkatkan harkat dan martabat pekerja sehingga timbul kepercayaan diri untuk mengembangkan kemampuannya (Heni, 2011).

Ada 7 faktor lingkungan kerja fisik yaitu tata ruang, penerangan, warna, kelembaban udara, musik, suara atau tingkat kebisingan. Penerangan cahaya lampu harus sesuai dengan kebutuhan karyawan, warna cat yang membuat nyaman dalam bekerja, udara yang sejuk sangat diperlukan dalam bekerja, musik perlu diadakan sehingga membuat karyawan merasa bersemangat dalam bekerja, suara atau tingkat kebisingan harus dapat diatasi sekecil mungkin (Suma'mur, 2014). 


\section{SEHATI}

Jurnal Kesehatan
Vol 1, No 2, Agustus 2021, p. 47-56

e-ISSN : 2775-6963 | p-ISSN : 2775-6955

DOI: https://doi.org/10.52364/sehati.v1i2.6

Selain lingkungan kerja fisik, yang juga harus diperhatikan adalah lingkungan kerja non fisik. Lingkungan kerja non fisik terdiri dari budaya kerja, kebiasaan, behavior based safety (BBS), peraturan persediaan serta ketersediaan sarana dan prasarana. Kondisi dukungan sosial yang rendah dapat berpengaruh terhadap peningkatan resiko stres, gangguan mental yang umum, depresi ataupun sakit kepala, sakit leher dan peningkatan suhu tubuh. Untuk menjaga dukungan sosial dan produktivitas kerja diperlukan hubungan antar karyawan dan rekan kerja yang baik. Selain itu lama kerja atau waktu kerja seseorang juga dapat berdampak terhadap pekerjaan setiap hari dari tempat atau lingkungan kerja.

PT. Mitra Bumi adalah sebuah perusahaan yang bergerak dibidang pengolahan minyak mentah kelapa sawit. Pabrik Kelapa Sawit ini juga mempunyai kebun sawit sendiri sebagai pemasok untuk operasionalnya pabrik. Perusahaan ini berada di Bangkinang Kabupaten Kampar. Berdasarkan studi pendahuluan yang dilakukan pada pekerja di pabrik kelapa sawit, terlihat bahwa dalam penggunaan alat pelindung diri banyak pekerja yang masih tidak menggunakannya. Pelindung kepala mereka ganti dengan kain atau topi biasa dan alat pelindung kaki hanya menggunakan sendal jepit. Perusahaan tidak menyediakan APD untuk pekerja, APD ditanggung sendiri oleh pekerja. Padahal alat pelindung diri ini bisa menjauhkan risiko kecelakaan dan penyakit akibat kerja. Para pekerja bongkar muat perkebunan kelapa sawit yang diwawancara tidak mengetahui fungsi dari APD dan dampak tidak menggunakan APD, mereka menganggap APD itu tidak perlu dan hanya menjadi beban ketika mereka bekerja. Ketersediaan APD yang terbatas juga menjadi kendala. Selain itu, tidak adanya pengawasan atau teguran ketika bekerja juga menjadi salah satu penyebab mereka tidak menggunakan APD.

Berdasarkan latar belakang tersebut penulis ingin melakukan penelitian mengenai pengaruh lingkungan kerja fisik dan lingkungan kerja non fisik terhadap tindakan Keselamatan dan Kesehatan Kerja (K3) di PT. Mitra Bumi.

\section{METODE PENELITIAN}

Penelitian ini dilaksanakan di Pabrik Kelapa Sawit PT. Mitra Bumi dari bulan Januari-Maret 2020. Jenis penelitian ini adalah penelitian kuantitatif dengan pendekatan cross sectional study. Data yang digunakan yaitu data primer. Populasi pada penelitian ini adalah seluruh pekerja pabrik kelapa sawit PT. Mitra Bumi yang berjumlah 57 orang. Cara pengambilan sampel yang digunakan yaitu total sampling, yaitu seluruh populasi dijadikan sampel. Analisis data dilakukan dengan uji ANOVA.

\section{HASIL DAN PEMBAHASAN}

\section{Lingkungan Kerja Fisik}

\section{Kelembaban Udara}

Kelembaban udara (humidity gauge) adalah jumlah uap air diudara (atmosfer). Kelembaban adalah konsentrasi uap air di udara. Kelembaban udara adalah tingkat kebasahan udara karena dalam udara air selalu terkandung dalam bentuk uap air. Angka konsentasi ini dapat diekspresikan dalam kelembaban absolut, kelembaban spesifik atau kelembaban relatif. Alat yang digunakan untuk mengukur kelembaban disebut dengan higrometer.

Berdasarkan hasil pengukuran yang dilakukan, didapatkan hasil penelitian seperti pada Tabel 1:

Tabel 1. Kelembaban Udara di PT. Mitra Bumi

\begin{tabular}{|c|c|c|c|c|c|c|c|c|}
\hline \multirow{2}{*}{ No } & \multirow{2}{*}{ Lokasi } & \multicolumn{6}{|c|}{ Pengukuran } & \multirow{2}{*}{ Rata-Rata } \\
\hline & & I & II & II & III & $\mathrm{V}$ & VI & \\
\hline 1 & $\begin{array}{c}\text { Stasiun Penerimaan } \\
\text { Buah }\end{array}$ & 31,60 & 30,50 & 39,40 & 35,20 & 31,30 & 31,40 & 33,23 \\
\hline 2 & Stasiun Rebusan & 31,90 & 32,20 & 34,30 & 33,30 & 31,80 & 32,40 & 32,65 \\
\hline 3 & Stasiun Pemipihan & 31,30 & 31,70 & 85,00 & 85,01 & 37,10 & 30,90 & 50,17 \\
\hline 4 & $\begin{array}{l}\text { Stasiun Pencacahan } \\
\text { dan Pengempaan }\end{array}$ & 34,00 & 34,90 & 34,00 & 34,80 & 85,01 & 30,10 & 42,14 \\
\hline 5 & Stasiun pemurnian & 36,20 & 35,10 & 36,40 & 35,90 & 30,40 & 85,04 & 43,17 \\
\hline 6 & $\begin{array}{c}\text { Stasiun Nut dan } \\
\text { Kernel }\end{array}$ & 38,50 & 38,50 & 37,50 & 39,80 & 36,60 & 38,50 & 38,23 \\
\hline
\end{tabular}

Sumber: Data Peneliti (2020)

Berdasarkan Tabel 1. dapat dilihat bahwa kelembaban yang cukup tinggi terdapat di stasiun pemipihan dengan rata-rata 50,17 dan kelembaban terendah terdapat di stasiun rebusan dengan rata-rata 32,65. Persyaratan Keputusan Menteri Kesehatan Republik Indonesia Nomor 1405/MENKES/SK/XI/2002 Tentang Persyaratan Kesehatan Lingkungan Kerja Perkantoran dan 


\section{SEHATI}

Jurnal Kesehatan
Vol 1, No 2, Agustus 2021, p. 47-56

e-ISSN : 2775-6963 | p-ISSN : 2775-6955

DOI: https://doi.org/10.52364/sehati.v1i2.6

Industri standar kelembaban adalah $40 \%$-60 \%. Hal ini berarti kelembaban di lingkungan kerja PT. Mitra Bumi masih belum memenuhi standar kesehatan.

Penelitian oleh Ikhsani (2019) di PT. Perkebunan Nusantara VII menunjukkan bahwa hasil ukur kelembaban berkisar antara 31,3-34\%. Hal ini berarti kelembaban di lingkungan kerja PT. Perkebunan Nusantara VII juga masih belum memenuhi standar kesehatan. Pada hasil observasi pengukuran dan pencatatan di area Loading Ramp, Sterilizer, Trasher serta Digester dan Press didapatkan kelembaban 31,5\%, 31,9\%, 31,3\% serta 34,0\%. Pada pengukuran kelembaban didapatkan selisih antara Nilai Ambang Kelembaban normal dengan hasil pengukuran sebesar $\pm 53 \%$. Perbedaan hasil pengukuran yang melebihi batas normal merupakan salah satu bahaya potensial fisik terhadap para pekerja.

Kelembaban lingkungan kerja sangat berkaitan dengan efektivitas pekerjaan. Bekerja pada lingkungan yang terlalu panas dan lembab dapat menurunkan kemampuan fisik tubuh serta dapat menyebabkan keletihan yang datang terlalu dini. Tingkat kelembaban udara yang terdapat pada lingkungan kerja akan mempengaruhi tingkat penyerapan atau pelepasan panas tubuh seseorang melalui proses evaporasi pada permukaan kulit. Pada kondisi suhu udara dan dinding yang tinggi, tingkat hilangnya panas (heat loss) tubuh melalui cara konveksi dan radiasi adalah sangat rendah. Pada kondisi ini heat loss terjadi melalui proses evaporasi. Jika kelembaban udara tinggi, evaporasi tidak dapat berlangsung sehingga dapat mengakibatkan naiknya suhu tubuh.

\section{Suhu Udara}

Suhu adalah ukuran derajat panas atau dingin suatu benda. Alat yang digunakan untuk mengukur suhu disebut termometer. Suhu menunjukkan derajat panas benda. Mudahnya, semakin tinggi suhu suatu benda, semakin panas benda tersebut. Secara mikroskopis, suhu menunjukkan energi yang dimiliki oleh suatu benda. Setiap atom dalam suatu benda masing - masing bergerak, baik itu dalam bentuk perpindahan maupun gerakan di tempat berupa getaran. Makin tingginya energi atom - atom penyusun benda, makin tinggi suhu benda tersebut.

Berdasarkan hasil pengukuran yang dilakukan, didapatkan hasil penelitian seperti pada Tabel 2:

Tabel 2. Suhu Udara di PT. Mitra Bumi

\begin{tabular}{ccccccccc}
\hline No & Lokasi & \multicolumn{9}{c}{ Pengukuran } & Rata-Rata \\
\cline { 3 - 7 } & & I & II & III & IV & V & VI & \\
1 & Stasiun Penerimaan & 40,20 & 41,80 & 37,80 & 48,60 & 44,00 & 40,20 & 42,10 \\
& Buah & & & & & & & \\
2 & Stasiun Rebusan & 35,80 & 36,40 & 38,20 & 33,10 & 31,10 & 35,40 & 35,00 \\
3 & Stasiun Pemipihan & 35,60 & 27,00 & 26,80 & 35,80 & 36,20 & 36,30 & 32,95 \\
4 & Stasiun Pencacahan dan & 39,20 & 39,10 & 34,90 & 25,90 & 34,70 & 38,40 & 35,37 \\
& Pengempaan & & & & & & & \\
5 & Stasiun pemurnian & 40,10 & 40,40 & 41,20 & 42,20 & 40,26 & 40,10 & 40,71 \\
6 & Stasiun Nut dan Kernel & 32,50 & 31,50 & 33,50 & 36,20 & 31,60 & 32,10 & 32,90 \\
\hline
\end{tabular}

Sumber: Data Peneliti (2020)

Suhu udara tertinggi berada pada stasiun penerimaan buah dengan rata-rata $42,1^{0} \mathrm{C}$ dan suhu udara terendah berada di stasiun nut dan kernel dengan rata-rata $32,9^{0} \mathrm{C}$. Persyaratan Keputusan Menteri Kesehatan Republik Indonesia Nomor 1405/MENKES/SK/XI/2002 Tentang Persyaratan Kesehatan Lingkungan Kerja Perkantoran dan Industri standar suhu di tempat kerja berada pada rentang $18^{\circ} \mathrm{C}-$ $28^{\circ} \mathrm{C}$.

Penelitian oleh Ikhsani (2019) di PT. Perkebunan Nusantara VII menunjukkan bahwa hasil ukur kelembaban berkisar antara $34,7-37,1^{\circ} \mathrm{C}$. Hal ini berarti suhu di lingkungan kerja PT. Perkebunan Nusantara VII juga masih belum memenuhi standar kesehatan. Pada hasil observasi pengukuran dan pencatatan di area Loading Ramp, Sterilizer, Trasher serta Digester dan Press didapatkan suhu $36,3^{\circ} \mathrm{C}, 36,8^{\circ} \mathrm{C}$, $34,7^{\circ} \mathrm{C}$ serta $37,1^{\circ} \mathrm{C}$. Pada pengukuran suhu didapatkan selisih antara Nilai Ambang Suhu normal dengan hasil pengukuran sebesar $\pm 7^{\circ} \mathrm{C}$. Perbedaan hasil pengukuran yang melebihi batas normal merupakan salah satu bahaya potensial fisik terhadap para pekerja.

Suhu udara dan kelembaban lingkungan kerja sangat berpengaruh pada efektivitas pekerjaan. Kenyamanan tubuh dapat ditentukan dari proses perpindahan panas dari tubuh ke lingkungan atau sebaliknya. Panas yang ditimbulkan oleh tubuh melalui proses metabolisme tubuh dan kerja otot akan ditransfer ke lingkungan melalui proses konveksi, radiasi dan evaporasi. Proses konduksi dapat dilakukan melalui kontak antara tubuh dengan permukaan benda panas atau dingin. Ketidaknyamanan (discomfort) dapat ditimbulkan oleh respon fisiologis tubuh terhadap suhu dan kelembaban udara yang berada di luar comfort zone. Derajat ketidaknyamanan tersebut antara lain dapat diketahui dengan mengukur skin surface 


\section{SEHATI}

Jurnal Kesehatan
Vol 1, No 2, Agustus 2021, p. 47-56

e-ISSN : 2775-6963 | p-ISSN : 2775-6955

DOI: https://doi.org/10.52364/sehati.v1i2.6

temperature (suhu permukaan kulit), sweating rate (laju pengeluaran keringat) dan cardiovascular (denyut jantung). Tingkat ketidaknyamanan yang disebabkan panas akan naik jika salah satu atau beberapa diantara parameter tadi mengalami kenaikan sehingga mengakibatkan heat discomfort atau heat stress.

Menurut Hidayati (2014) ketika tubuh manusia berada pada kondisi lingkungan dengan suhu udara tinggi maka tubuh akan berusaha memindahkan panas ke kulit yang mendorong peningkatan jumlah darah untuk dibawa ke otot, kondisi ini akan meningkatkan respon sistem cardiovaskular. Hal ini terlihat dari aktivitas jantung yang memompa darah lebih cepat sehingga terjadi peningkatan denyut jantung. Peningkatan rata-rata ini bervariasi, pada orang dengan kondisi fisik baik terjadi peningkatan denyut jantung yang kecil. Menurut Wita (2016) peningkatan rata-rata denyut jantung berkisar antara 180 sampai $200 \mathrm{kali} / \mathrm{menit}$ yang merupakan nilai maksimal untuk usia dewasa.

Suhu udara tertinggi berada pada stasiun penerimaan buah dengan rata-rata $42,1^{\circ} \mathrm{C}$ dan suhu udara terendah berada di stasiun nut dan kernel dengan rata-rata $32,9^{\circ} \mathrm{C}$. Nilai ini menunjukkan bahwa rata-rata tingkat temperatur yang ada berada di luar nilai ambang batas yang ditetapkan. Hal tersebut disebabkan oleh kurangnya sirkulasi udara, alat/mesin yang dapat menimbulkan panas, dan bahkan tidak adanya terdapat peralatan penurun suhu di perusahaan seperti Exhaust Fan (Turbin Ventilator).

Menurut Utama (2019) Panas lingkungan yang melebihi nilai ambang batas dapat menyebabkan gangguan performansi kerja seperti keletihan yang datang terlalu dini dan kehilangan cairan tubuh atau dehidrasi. Dalam mengatasi hal tersebut, perusahaan perlu mengambil langkah yang strategis untuk bisa menurunkan suhu tersebut pada nilai ambang batas yang ditetapkan. Langkah yang dapat dilakukan oleh perusahaan dalam mengatasi gangguan kerja tersebut adalah dengan memperbaiki ruang sirkulasi udara di area kerja agar terjadi sirkulasi udara yang baik, penyediaan kipas angin di setiap titik ruangan kerja, menggunakan pakaian yang mampu menstabilkan tubuh, sehingga dapat mengurangi panas yang terjadi, dan penyediaan peralatan penurun suhu seperti menggunakan exhaust fan atau turbin ventilator.

Iklim kerja adalah hasil perpaduan antara suhu, kelembaban, kecepatan gerakan udara dan panas radiasi dengan tingkat pengeluaran panas dari tubuh tenaga kerja sebagai akibat pekerjaannnya. Iklim kerja panas merupakan pengaruh dari lingkungan kerja yang disebabkan oleh gerakan angin, kelembaban, suhu udara, suhu radiasi, dan sinar matahari. Orang- orang Indonesia pada umumnya beraklimatisasi dengan iklim tropis yang suhunya sekitar $29^{\circ} \mathrm{C}-30^{\circ} \mathrm{C}$ dengan kelembaban sekitar $85-95 \%$. Suhu nikmat sekitar $24^{\circ} \mathrm{C}-26^{\circ} \mathrm{C}$, bagi orang-orang Indonesia. Suhu panas berakibat menurunnya prestasi kerja dan cara berpikir. Penurunan sangat hebat sesudah $32^{\circ} \mathrm{C}$ (Wulandari, 2018). Bahaya potensial fisik pada iklim kerja ini dapat menyebabkan gangguan kesehatan pada pekerja, seperti dehidrasi, nyeri kepala, badan mudah lelah, heat rush, heat fatigue, heat exhaustion, dan heat sincope.

\section{Pencahayaan}

Pencahayaan adalah jumlah penyinaran pada suatu bidang kerja yang diperlukan untuk melaksanakan kegiatan secara efektif. Prinsip penerangan yang baik adalah jumlah dan intensitas penerangan yang diperlukan hendaknya disesuaikan dengan jenis pekerjaan, daya lihat seseorang dan lingkungannya.

Berdasarkan hasil pengukuran yang dilakukan, didapatkan hasil penelitian seperti pada Tabel 3:

Tabel 3. Pencahayaan di PT. Mitra Bumi

\begin{tabular}{|c|c|c|c|c|c|c|c|c|}
\hline \multirow{2}{*}{ No } & \multirow{2}{*}{ Lokasi } & \multicolumn{6}{|c|}{ Pengukuran } & \multirow{2}{*}{$\begin{array}{l}\text { Rata- } \\
\text { Rata }\end{array}$} \\
\hline & & I & II & III & IV & $\mathrm{V}$ & VI & \\
\hline 1 & Stasiun Penerimaan Buah & 13,00 & 10,00 & 14,30 & 10,60 & 11,80 & 12,70 & 12,07 \\
\hline 2 & Stasiun Rebusan & 93,00 & 68,00 & 84,00 & 87,40 & 84,60 & 96,60 & 85,60 \\
\hline 3 & Stasiun Pemipihan & 23,00 & 22,10 & 26,80 & 22,00 & 21,90 & 22,80 & 23,10 \\
\hline 4 & $\begin{array}{l}\text { Stasiun Pencacahan dan } \\
\text { Pengempaan }\end{array}$ & 7,00 & 6,00 & 6,80 & 8,80 & 9,80 & 4,90 & 7,22 \\
\hline 5 & Stasiun pemurnian & 10,00 & 11,00 & 10,70 & 10,90 & 12,10 & 16,10 & 11,80 \\
\hline 6 & Stasiun Nut dan Kernel & 10,40 & 15,90 & 15,00 & 7,50 & 8,10 & 5,20 & 10,35 \\
\hline
\end{tabular}

Berdasarkan Tabel 3 dapat dilihat bahwa pencahayaan tertinggi terdapat di stasiun rebusan dengan pencahayaan 85,6 lux dan pencahayaan terendah berada di stasiun pencacahan dan pengempaan dengan pencahayaan 7,22 lux. Persyaratan Keputusan Menteri Kesehatan Republik Indonesia Nomor 1405/MENKES/SK/XI/2002 Tentang Persyaratan Kesehatan Lingkungan Kerja Perkantoran dan Industri standar intensitas cahaya di tempat kerja minimal 100 lux. Oleh karena itu, pencahayaan di PT. Mitra Bumi belum memenuhi standar. 


\section{SEHATI}

Jurnal Kesehatan
Vol 1, No 2, Agustus 2021, p. 47-56

e-ISSN : 2775-6963 | p-ISSN : 2775-6955

DOI: https://doi.org/10.52364/sehati.v1i2.6

Penelitian oleh Ikhsani (2019) di PT. Perkebunan Nusantara VII menunjukkan bahwa hasil ukur pencahayaan berkisar antara 7 hingga 93 lux. Hal ini berarti pencahayaan di lingkungan kerja PT. Perkebunan Nusantara VII juga masih belum memenuhi standar kesehatan. Pencahayaan yang tidak memadai pada lingkungan kerja menyebabkan beberapa masalah yang dapat merugikan seperti pada aspek psikologis, yang dapat dirasakan sebagai kelelahan rasa kurang nyaman, kurang kewaspadaan sampai kepada pengaruh yang terberat seperti kecelakaan.

Pencahayaan merupakan faktor yang sangat penting dalam suatu perusahaan atau pabrik karena dapat memperlancar pekerjaan para pekerja. Penerangan yang cukup akan menambah semangat kerja pekerja, karena mereka dapat lebih cepat menyelesaikan tugas-tugasnya, matanya tidak mudah lelah karena cahaya yang gelap, dan kesalahan-kesalahan dapat dihindari. Banyak kesalahan pekerjaan disebabkan karena penerangan yang buruk, misalnya ruangan yang terlampau gelap atau karyawan harus bekerja di bawah penerangan yang menyilaukan. Penerangan atau cahaya yang cukup merupakan pertimbangan yang penting dalam fasilitas fisik suatu perusahaan. Pelaksanaan pekerjaan yang sukses memerlukan penerangan yang baik.

Pencahayaan ruangan, khususnya di tempat kerja yang kurang memenuhi persyaratan dapat memperburuk penglihatan, pencahayaan yang terlalu besar atau pun lebih kecil, pupil mata harus berusaha menyesuaikan cahaya yang diterima oleh mata. Hal ini diperkuat dari hasil wawancara yang dilakukan pada pekerja di pabrik pengolahan kelapa sawit didapatkan keluhan berupa pegal di area sekitar mata, iritasi dan sakit kepala. Intensitas penerangan merupakan aspek penting di tempat kerja. Berbagai masalah akan timbul ketika kualitas intensitas penerangan di tempat kerja tidak memenuhi standar yang ditetapkan. Intensitas penerangan yang kurang akan meningkatkan potensi kecelakaan kerja, keluhan yang tampak dapat berupa kelelahan mata, daya akomodasi menurun, konjungtivitis (Ayu, 2013).

\section{Kebisingan}

Kebisingan adalah semua suara yang tidak dikehendaki yang bersumber dari alat-alat proses produksi dan atau alat-alat kerja yang pada tingkat tertentu dapat menimbulkan gangguan pendengaran (Kepmennaker No. KEP-51.MEN/1999).

Berdasarkan hasil pengukuran yang dilakukan, didapatkan hasil penelitian seperti pada Tabel 4:

Tabel 4. Kebisingan di PT. Mitra Bumi

\begin{tabular}{lcccccccc}
\hline \multirow{2}{*}{ No } & Lokasi & \multicolumn{4}{c}{ Pengukuran } & Rata-Rata \\
\cline { 3 - 8 } & Stasiun Penerimaan Buah & 87,65 & 85,00 & 88,50 & 92,60 & 90,00 & 93,80 & 89,59 \\
2 & Stasiun Rebusan & 90,00 & 90,20 & 84,89 & 84,98 & 87,90 & 90,40 & 88,06 \\
3 & Stasiun Pemipihan & 93,60 & 84,92 & 97,60 & 85,00 & 90,10 & 90,20 & 90,24 \\
4 & Stasiun Pencacahan dan & 94,40 & 94,60 & 93,00 & 93,80 & 94,10 & 89,90 & 93,30 \\
5 & Pengempaan & 95,23 & 97,40 & 95,20 & 95,90 & 100,20 & 101,00 & 97,49 \\
6 & Stasiun pemurnian & 97,30 & 91,30 & 94,60 & 100,40 & 97,00 \\
\hline
\end{tabular}

Sumber: Data Peneliti (2020)

Berdasarkan Tabel 4 dapat dilihat bahwa kebisingan tertinggi berada di stasiun pemurnian dengan kebisingan 97,49 dB dan kebisingan terendah berada pada stasiun rebusan dengan kebisingan 88,06 dB. Nilai Ambang Batas kebisingan merupakan nilai yang mengatur tentang tekanan bising rata-rata atau level kebisingan berdasarkan durasi pajanan bising yang mewakili kondisi dimana hampir semua pekerja terpajan bising berulang-ulang tanpa menimbulkan gangguan pendengaran dan memahami pembicaraan normal. NAB kebisingan untuk 8 jam kerja per hari adalah sebesar $85 \mathrm{dBA}$. Apabila seorang pekerja terpajan bising di tempat kerja tanpa menggunakan alat pelindung telinga selama 8 jam kerja per hari, maka NAB pajanan bising yang boleh diterima oleh pekerja tersebut adalah $85 \mathrm{dBA}$ (Permenkes No. 70 Tahun 2016). Nilai ini menunjukkan bahwa rata-rata tingkat kebisingan berada di luar nilai ambang batas yang telah ditetapkan. Berdasarkan fakta di lapangan, hal ini disebabkan oleh suara mesin yang keras dan dekat dengan tempat kerja operator.

Penelitian oleh Ikhsani (2019) di PT. Perkebunan Nusantara VII menunjukkan bahwa hasil ukur kebisingan berkisar 93,03 hingga 93,96 dB. Hal ini berarti kebisingan di lingkungan kerja PT. Perkebunan Nusantara VII juga masih belum memenuhi standar kesehatan. Rata-rata pekerja di PTPN VII Unit Usaha Bekri memiliki pembagian jam kerja dibagi menjadi 2 shift selama 8 jam yang memiliki jeda istirahat, jam kerja mereka juga dipengaruhi dengan hasil panen. Jika hasil panen sedang banyak maka pekerja bisa berkerja selama 12 jam perhari selama 7 hari biasanya pada triwulan ke 4 . Jika kita bandingkan hasil observasi akan didapatkan hasil sesuai pada jumlah jam kerja karena memiliki jeda istirahat, sementara 


\section{SEHATI}

Jurnal Kesehatan
Vol 1, No 2, Agustus 2021, p. 47-56

e-ISSN : 2775-6963 | p-ISSN : 2775-6955

DOI: https://doi.org/10.52364/sehati.v1i2.6

untuk tingkat kebisingan telah melewati nilai ambang batas yaitu $>85 \mathrm{~dB}(8)$. Dari sisi lama waktu bekerja sudah melebihi untuk satu triwulan tapi untuk 3 triwulan lain nya masih dalam batas standar yang diperbolehkan kondisi ini apabila berlangsung terus menerus pada pekerja akan menimbulkan efek pada sistem pendengaran dan sistem lainnya.

Dampak dari penggunaan mesin-mesin berkapasitas besar di pabrik adalah kebisingan yang ditimbulkan oleh aktivitas mesin-mesin pengolahan, bising saat pembuangan steam oleh back pressure vessel di ruang mesin dan saat pembuangan steam bekas perebusan di stasiun sterilizer. Kebisingan merupakan terjadinya bunyi yang tidak dikehendaki termasuk bunyi yang tidak beraturan dan bunyi yang dikeluarkan oleh transportasi dan industri, sehingga dalam jangka waktu yang panjang akan dapat mengganggu dan membahayakan konsentrasi kerja, merusak pendengaran (kesehatan) dan mengurangi efektivitas kerja. Kebisingan dapat menimbulkan pengaruh negatif pada tenaga kerja berupa gangguan-gangguan diantaranya gangguan fisiologis, gangguan psikologis, gangguan komunikasi, gangguan keseimbangan dan efek pada pendengaran. Pengendalian kebisingan dapat dilakukan dengan beberapa cara yaitu pengendalian secara teknis (engineering control), pengendalian administratif (administrative control) dan pemakaian alat pelindung diri.

Beberapa hal yang dapat dilakukan untuk mengurangi dampak yang dihasilkan akibat kebisingan lingkungan kerja adalah dengan mengendalikan pada sumber bising, yaitu dengan mengurangi tingkat kebisingan yang dihasilkan oleh suatu mesin. Misalnya dengan menggunakan mesin-mesin dengan tingkat bising yang rendah, menempatkan mesin-mesin yang menghasilkan suara bising jauh dari jangkauan pekerja, atau menutup sumber bising tersebut; mengendalikan pada medium, yaitu yang menjadi perantara kebisingan. Misalnya merancang penghalang akustik, peredam suara, atau memutus jalur getaran melalui struktur dengan memasang vibration absorber; dan mengendalikan pada penerima, yaitu dengan menggunakan alat pelindung diri (APD) untuk mengurangi dampak kebisingan secara langsung. Alat pelindung diri yang dapat digunakan untuk mengurangi dampak kebisingan adalah earplug atau earmuff.

Gangguan kebisingan yang melebihi ambang batas waktu dapat mengakibatkan gangguan auditory berupa tinitus, tuli sementara dan tuli menetap (Azmi, 2016). Selain itu gangguan non auditory juga dapat timbul pada kebisingan yang melebihi ambang batas yaitu gangguan komunikasi (Silitonga, 2016), gangguan psikologis (Ayu, 2013), dan gangguan keseimbangan (Kholik, 2012).

\section{Hasil Uji Anova}

Anova adalah sebuah analisis statistik yang menguji perbedaan rerata antar grup merupakan singkatan dari Analysis of variance. Uji anova merupakan prosedur uji statistik yang mirip dengan $\mathrm{t}$ test. Anova digunakan sebagai alat analisis untuk menguji hipotesis penelitian yang mana menilai adakah perbedaan rerata antara kelompok. Hasil akhir dari analisis ANOVA adalah nilai $\mathrm{F}$ test atau $\mathrm{F}$ hitung. Berdasarkan uji anova yang telah dilakukan, didapatkan hasil seperti pada Tabel 5:

Tabel 5. Hasil Uji Anova Lingkungan Kerja Fisik

\begin{tabular}{lrrrrrr}
\hline \multicolumn{1}{c}{ Source of Variation } & \multicolumn{1}{c}{$S S$} & \multicolumn{1}{c}{$d f$} & \multicolumn{1}{c}{$M S$} & \multicolumn{1}{c}{$F$} & $P$-value & F crit \\
\hline Between Groups & 2,4 & 3 & 0,8 & 4,571428571 & 0,0170145 & 3,2388715 \\
Within Groups & 2,8 & 16 & 0,175 & & & \\
Total & 5,2 & 19 & & & & \\
\end{tabular}

Sumber: Data Peneliti (2020)

Berdasarkan hasil anova pada variabel lingkungan fisik diketahui bahwa ada pengaruh signifikan karena $\mathrm{F}$ hitung lebih besar daripada $\mathrm{F}$ tabel $(4,57>3,23)$, sehingga Ho ditolak berarti ada pengaruh terhadap tindakan Keselamatan dan Kesehatan Kerja (K3). Oleh karena itu, dilakukan uji pasca anova yaitu uji Schefee dan uji Tukey.

Berdasarkan hasil uji Schefee ternyata hanya ada satu pasangan variabel yang rata-ratanya berbeda secara signifikan yaitu pasangan variabel $t_{3}$. Nilai $t$ untuk pasangan tersebut adalah 3,46 yang lebih besar dari nilai kritis uji schefee $\left.\left(t_{s}\right)=3,05\right)$ seperti pada lampiran 5. Oleh karena itu dapat diketahui variabel lingkungan kerja fisik yang berpengaruh secara signifikan yaitu pasangan cariabel t 3 yang terdapat pada variabel pencahayaan dan kebisingan.

Berdasarkan hasil uji Tukey diketahui perbedaan antara rata-rata setiap pasangannya. Oleh sebab itu hasil tersebut menunjukkan satu buah nilai kontras (C) antara rata-rata setiap pasangan yang lebih besar daripada nilai kritis HSD, dengan kata lain uji Tukey menghasilkan satu kontras yang signifikan 


\section{SEHATI}

Jurnal Kesehatan
Vol 1, No 2, Agustus 2021, p. 47-56

e-ISSN : 2775-6963 | p-ISSN : 2775-6955

DOI: https://doi.org/10.52364/sehati.v1i2.6

pada $p<0,05$ yaitu kontras $C_{3}\left(X_{1}\right.$ dan $\left.X_{4}\right)$ seperti pada lampiran 5. Nilai $X_{1}$ dan $X_{4}$ terdapat pada variabel pencahayaan dan kebisingan.

\section{Lingkungan Kerja Non Fisik}

\section{Pengetahuan}

Pengetahuan merupakan hasil dari tahu seseorang dan terjadi setelah orang tersebut melakukan penginderaan terhadap suatu ojek tertentu. Pengetahuan atau kognitif merupakan domain yang sangat penting dalam membentuk tindakan seseorang (over behavior). Perilaku yang didasari oleh pengetahuan akan lebih baik daripada perilaku yang tidak didasari oleh pengetahuan, biasanya pengetahuan seseorang diperoleh dari pengalaman yang berasal dari berbagai macam sumber (Notoatmodjo, 2010).

Peningkatan pengetahuan tidak selalu menyebabkan perubahan perilaku, tetapi pengetahuan sangat penting diberikan sebelum individu melakukan suatu tindakan. Tindakan akan sesuai dengan pengetahuan apabila individu menerima isyarat yang cukup kuat untuk memotivasi dirinya untuk bertindak sesuai dengan pengetahuannya. Teori Bloom menjelaskan bahwa perilaku tidak hanya dipengaruhi oleh pengetahuan saja (faktor predisposisi), akan tetapi dapat dipengaruhi oleh faktor pendukung (ketersediaan APD) dan faktor pendorong (pengawasan dan peraturan).

\section{Behavior Based Safety}

Behavior Based Safety adalah suatu proses untuk mengamati perilaku kritis (tak aman maupun aman) dari pekerja, menganalisis penyebabnya dan menentukan upaya untuk meningkatkan perilaku aman secara berkesinambungan berdasarkan umpan balik dan kerja sama dari pekerja. Behavior Based Safety adalah pola perilaku keselamatan kerja dari sebagian besar anggota organisasi/perusahaan, yang diwujudkan dalam bentuk sikap dan tindakan yang mengarah pada terciptanya kegiatan kerja yang aman.

Solekhah (2018) mengungkapkan bahwa kejadian kecelakaan kerja dapat dicegah dengan cara memperhatikan perilaku pekerja. Kesehatan dan keselamatan kerja dan sakit akibat kerja dapat dikurangi melalui cara pekerja taat sesuai Standar Operasional Prosedur (SOP). Hal ini diharapkan peraturan yang telah disepakati perusahaan dapat dipatuhi oleh pekerja guna mengurangi risiko kecelakaan kerja. Pekerja yang tidak patuh dalam pelaksanaan SOP dapat mengalami kecelakaan dalam bekerja maupun penyakit akibat bekerja seperti kekacauan organisasi, kerusakan, kelainan, keluhan, kesedihan, cacat dan kematian.

\section{Ketersediaan Alat}

Perubahan perilaku didasari adanya perubahan atau penambahan pengetahuan sikap dan keterampilannya. Namun demikian, perubahan pengetahuan dan sikap ini belum merupakan jaminan terjadinya perubahan perilaku sebab perilaku tersebut kadang- kadang memerlukan dukungan material dan penyediaan sarana (enabling factors). APD harus tersedia cukup jenis dan jumlahnya, untuk perlindungan seluruh atau sebagian tubuh (Notoadmodjo, 2010). Peraturan Menteri Tenaga Kerja dan Transmigasi RI Nomor Per.08/MEN/VII/2010 tentang Alat Pelindung Diri menjelaskan bahwa pengusaha wajib menyediakan APD bagi pekerja/buruh di tempat kerja.

\section{Peraturan Perusahaan}

Peraturan perusahaan adalah peraturan yang dibuat secara tertulis oleh perusahaan, yang didalamnya memuat syarat-syarat kerja dan tata tertib perusahaan (UU No. 13 Tahun 2003 tentang Ketenagakerjaan). Sebuah peraturan perusahaan baru dikatakan sah dan mengikat perusahaan dan karyawan apabila telah mendapatkan pengesahan dari Menteri Ketenagakerjaan dan Transmigrasi. Pengesahan itu dilakukan oleh pejabat yang ditunjuk, yaitu kepala instansi yang bertanggung jawab di bidang ketenagakerjaan Kabupaten/Kota (untuk perusahaan yang terdapat dalam satu Kabupaten/Kota) dan kepala instansi yang bertanggung jawab di bidang ketenagakerjaan tingkat Provinsi (untuk perusahaan yang terdapat dalam lebih dari satu wilayah Kabupaten/Kota).

\section{Uji Anova Variabel Lingkungan Kerja Non Fisik}

Anova adalah sebuah analisis statistik yang menguji perbedaan rerata antar grup merupakan singkatan dari Analysis of variance. Uji anova merupakan prosedur uji statistik yang mirip dengan $\mathrm{t}$ test. Anova digunakan sebagai alat analisis untuk menguji hipotesis penelitian yang mana menilai adakah perbedaan rerata antara kelompok. Hasil akhir dari analisis ANOVA adalah nilai $\mathrm{F}$ test atau $\mathrm{F}$ hitung. Berdasarkan uji anova yang telah dilakukan, didapatkan hasil seperti pada Tabel 6: 
Tabel 6. Hasil Uji Anova Lingkungan Kerja Non Fisik

\begin{tabular}{lrrrrrr}
\hline $\begin{array}{l}\text { Source of } \\
\text { Variation }\end{array}$ & $S S$ & $d f$ & $M S$ & $F$ & P-value & F crit \\
\hline Between & 59,24616293 & 3 & 19,74872098 & 1,384955472 & 0,2508529 & 2,6821317 \\
Groups & & & & & \\
Within & 1668,357143 & 117 & 14,25946276 & & & \\
Groups & & & & & & \\
Total & 1727,603306 & 120 & & & & \\
\hline
\end{tabular}

Berdasarkan hasil anova pada variabel lingkungan kerja non fisik diketahui bahwa tidak ada pengaruh signifikan karena $\mathrm{F}$ hitung lebih kecil daripada $\mathrm{F}$ tabel $(1,38<2,68)$, sehingga Ho diterima berarti tidak ada pengaruh lingkungan kerja non fisik terhadap tindakan Keselamatan dan Kesehatan Kerja (K3). Artinya variabel pengetahuan, BBS, ketersediaan alat dan peraturan perusahaan tidak berhubungan dengan tindakan Keselamatan dan Kesehatan Kerja (K3).

\section{Faktor yang Paling Dominan pada Lingkungan Kerja Fisik dan Non Fisik}

Berdasarkan hasil pemetaan seperti terlihat pada bagan berikut:

\begin{tabular}{|c|c|c|c|c|c|c|c|c|c|}
\hline & \multirow{2}{*}{$\vec{\downarrow} \mathrm{Y}$} & \multicolumn{4}{|c|}{ Lingkungan Kerja Fisik } & \multicolumn{4}{|c|}{$\begin{array}{l}\text { Lingkungan Kerja Non } \\
\text { Fisik }\end{array}$} \\
\hline & & $\mathrm{X}_{1}$ & $\mathrm{X}_{2}$ & $\mathrm{X}_{3}$ & $\mathrm{X}_{4}$ & $\mathrm{X}_{5}$ & $\mathrm{X}_{6}$ & $\mathrm{X}_{7}$ & $\mathrm{X}_{8}$ \\
\hline \multirow{4}{*}{ 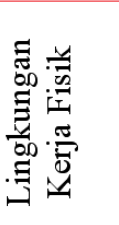 } & $\mathrm{X}_{1}$ & $8 x$ & 212.2. & X. & $\mathrm{X}_{14}$ & $\mathrm{X}_{15}$ & $\mathrm{X}_{16}$ & $\mathrm{X}_{17}$ & $\mathrm{X}_{18}$ \\
\hline & $\mathrm{X}_{2}$ & 2 & & - 2 - & $x=$ & $\mathrm{X}_{25}$ & $\mathrm{X}_{26}$ & $\mathrm{X}_{27}$ & $\mathrm{X}_{28}$ \\
\hline & $\mathrm{X}_{3}$ & $x-1$ & $x$ & $x-2$ & 3 & $\mathrm{X}_{35}$ & $\mathrm{X}_{36}$ & $\mathrm{X}_{37}$ & $\mathrm{X}_{38}$ \\
\hline & $\mathrm{X}_{4}$ & $x-$ & - & & - & $X_{45}$ & $\mathrm{X}_{46}$ & $\mathrm{X}_{47}$ & $\mathrm{X}_{48}$ \\
\hline \multirow{4}{*}{ 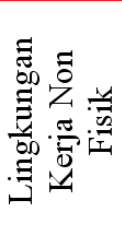 } & $\mathrm{X}_{5}$ & $\mathrm{X}_{51}$ & $\mathrm{X}_{52}$ & $\mathrm{X}_{53}$ & $\lambda_{54}$ & $\mathrm{X}_{55}$ & $\mathbb{X}_{56}$ & $\mathrm{X}_{57}$ & $\mathrm{X}_{58}$ \\
\hline & $\mathrm{X}_{6}$ & $\mathrm{X}_{61}$ & $\mathrm{X}_{62}$ & $\mathrm{X}_{63}$ & $\mathrm{X}_{64}$ & $\lambda_{65}$ & $\mathrm{X}_{66}$ & $x_{67}$ & $\mathrm{X}_{68}$ \\
\hline & $\mathrm{X}_{7}$ & $\mathrm{X}_{71}$ & $\mathrm{X}_{72}$ & $\mathrm{X}_{73}$ & $\mathrm{X}_{74}$ & $\mathrm{X}_{75}$ & & & \\
\hline & $\mathrm{X}_{8}$ & $\mathrm{X}_{81}$ & $\mathrm{X}_{82}$ & $\mathrm{X}_{83}$ & $\mathrm{X}_{84}$ & $\mathrm{X}_{85}$ & $\mathrm{X}_{86}$ & & \\
\hline
\end{tabular}

Gambar 1. Bagan Pemetaan Nilai untuk Setiap Indikator pada Variabel Fisik dan Non Fisik

Keterangan:

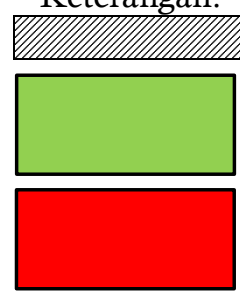

: Signifikan

: Variabel yang Berdiri Sendiri

: Faktor yang Paling Dominan dalam Lingkungan Kerja Fisik

Dari gambar 1 dapat dilihat bahwa terdapat 64 kemungkinan dan dikurangkan 8 variabel yang berdiri sendiri sehingga terdapat 56 kemungkinan. Dari bagan tersebut diperoleh 2 indikator yaitu $\mathrm{X}_{14}\left(\mathrm{X}_{1}\right.$ dan $\mathrm{X}_{4}$ ) yaitu pencahayaan dan kebisingan. Nilai untuk setiap indikator pada variabel fisik dan non fisik diperoleh 2 indikator yaitu $\mathrm{X}_{14}\left(\mathrm{X}_{1}\right.$ dan $\left.\mathrm{X}_{4}\right)$ yaitu pencahayaan dan kebisingan. Berdasarkan hasil penelitian diketahui bahwa pencahayaan tertinggi terdapat di stasiun rebusan dengan pencahayaan 85,6 lux dan pencahayaan terendah berada di stasiun pencacahan dan pengempaan dengan pencahayaan 7,22 lux. Persyaratan Keputusan Menteri Kesehatan Republik Indonesia Nomor 1405/MENKES/SK/XI/2002 Tentang Persyaratan Kesehatan Lingkungan Kerja Perkantoran dan Industri standar intensitas cahaya di tempat kerja minimal 100 lux. Oleh karena itu, pencahayaan di PT. Mitra Bumi belum memenuhi standar. 


\section{SEHATI}

Jurnal Kesehatan
Vol 1, No 2, Agustus 2021, p. 47-56

e-ISSN : 2775-6963 | p-ISSN : 2775-6955

DOI: https://doi.org/10.52364/sehati.v1i2.6

Pencahayaan yang tidak memadai menyebabkan ganguan pada mata seperti kelelahan pada mata, daya akomodasi menurun, dan konjungtivitis, jika ini tetap terjadi tanpa intervensi seperti penambahan lampu dengan intensitas cahaya yang disesuaikan dengan persyaratan tingkat pencahayaan, dan memastikan setiap pekerja mendapatkan penerangan yang sesuai dapat menurunkan risiko kecelakaan kerja. Untuk menyikapi kondisi tersebut dan menunjang kestabilan standarisasi tingkat pencahayaan di PT. Mitra Bumi, maka perusahaan perlu mengambil langkah-langkah baik dan strategis, sehingga tercapai lingkungan fisik kerja yang layak. Langkah-langkah yang dapat dilakukan untuk mengatasi tingkat pencahayaan yang kurang adalah dengan mengganti lampu yang telah mati atau redup dengan sumber cahaya listrik yang menyebar, merata, dan tidak menimbulkan kesilauan serta bayangan yang mengganggu, mendesain ulang layout tempat kerja dengan menambah penerangan alami dari luar ruangan, dan melakukan beberapa pemasangan atap transparan, sehingga cahaya matahari bisa masuk ke dalam gedung.

Pencahayaan yang tidak memadai pada lingkungan kerja menyebabkan beberapa masalah yang dapat merugikan seperti pada aspek psikologis, yang dapat dirasakan sebagai kelelahan rasa kurang nyaman, kurang kewaspadaan sampai kepada pengaruh yang terberat seperti kecelakaan. Pencahayaan ruangan, khususnya di tempat kerja yang kurang memenuhi persyaratan dapat memperburuk penglihatan, pencahayaan yang terlalu besar atau pun lebih kecil, pupil mata harus berusaha menyesuaikan cahaya yang diterima oleh mata. Hal ini diperkuat dari hasil wawancara yang dilakukan pada pekerja di pabrik pengolahan kelapa sawit didapatkan keluhan berupa pegal di area sekitar mata, iritasi dan sakit kepala. Intensitas penerangan merupakan aspek penting di tempat kerja. Berbagai masalah akan timbul ketika kualitas intensitas penerangan di tempat kerja tidak memenuhi standar yang ditetapkan. Intensitas penerangan yang kurang akan meningkatkan potensi kecelakaan kerja, keluhan yang tampak dapat berupa kelelahan mata, daya akomodasi menurun, konjungtivitis pada mata.

Berdasarkan hasil penelitian diketahui bahwa kebisingan tertinggi berada di stasiun pemurnian dengan tingkat kebisingan 97,49 $\mathrm{dB}$ dan kebisingan terendah berada pada stasiun rebusan dengan tingkat kebisingan 88,06 dB. Nilai Ambang Batas (NAB) kebisingan merupakan nilai yang mengatur tentang tekanan bising rata-rata atau level kebisingan berdasarkan durasi pajanan bising yang mewakili kondisi dimana hampir semua pekerja terpajan bising berulang-ulang tanpa menimbulkan gangguan pendengaran dan memahami pembicaraan normal. NAB kebisingan untuk 8 jam kerja per hari adalah sebesar $85 \mathrm{dBA}$. Apabila seorang pekerja terpajan bising di tempat kerja tanpa menggunakan alat pelindung telinga selama 8 jam kerja per hari, maka NAB pajanan bising yang boleh diterima oleh pekerja tersebut adalah $85 \mathrm{dBA}$ (Permenkes No. 70 Tahun 2016). Nilai ini menunjukkan bahwa rata-rata tingkat kebisingan berada di luar nilai ambang batas yang telah ditetapkan. Berdasarkan fakta di lapangan, hal ini disebabkan oleh suara mesin yang keras dan dekat dengan tempat kerja operator.

Suara bising yang keras, tajam dan tidak terduga adalah penyebab gangguan yang kerap dialami pekerja. Gangguan ini seringkali didiamkan saja walaupun tindakan perbaikan yang sederhana dapat dilakukan apabila waktu dan pikiran diluangkan untuk masalah itu. Sebagian besar dari pekerja pabrik merupakan pekerja yang membutuhkan konsentrasi pikiran, oleh karena itu diusahakan agar jangan banyak terjadi suara-suara gaduh. Seorang mungkin tidak menyadari pengaruh kegaduhan suara, tetapi setelah beberapa waktu orang akan menjadi sangat lelah dan lekas marah sebagai pengaruh suara yang gaduh. Gangguan kebisingan yang melebihi ambang batas waktu dapat mengakibatkan gangguan auditory berupa tinitus, tuli sementara dan tuli menetap (Azmi, 2016). Selain itu gangguan non auditory juga dapat timbul pada kebisingan yang melebihi ambang batas yaitu gangguan komunikasi (Silitonga, 2016), gangguan psikologis (Ayu, 2013), dan gangguan keseimbangan (Kholik, 2012).

\section{KESIMPULAN}

Terdapat hubungan lingkungan kerja fisik (pencahayaan, suhu, kebisingan dan kelembaban) terhadap tindakan Keselamatan dan Kesehatan Kerja (K3) di PT. Mitra Bumi. Tidak terdapat hubungan lingkungan kerja non fisik (pengetahuan pekerja, behavior based safety, ketersediaan alat dan peraturan perusahaan) terhadap tindakan Keselamatan dan Kesehatan Kerja (K3) di PT. Mitra Bumi. Faktor yang paling dominan terhadap tindakan Keselamatan dan Kesehatan Kerja (K3) di PT. Mitra Bumi adalah lingkungan kerja fisik yaitu pada pencahayaan dan kebisingan.

\section{UCAPAN TERIMAKASIH}

Ucapan terima kasih penulis sampaikan kepada pihak PT. Mitra Bumi yang telah memberikan data dan informasi sehingga terlaksananya penelitian ini di lapangan. 


\section{SEHATI}

Jurnal Kesehatan
Vol 1, No 2, Agustus 2021, p. 47-56

e-ISSN : 2775-6963 | p-ISSN : 2775-6955

DOI: https://doi.org/10.52364/sehati.v1i2.6

\section{DAFTAR PUSTAKA}

Ardani, H. N. Santoso, H. Rumita, R. 2013. Analisis Risiko Kesehatan Dan Keselamatan Kerja Pada Pekerja Divisi Mill Boiler (Studi Kasus Di PT. Laju Perdana Indah PG Pakis Baru, Pati. Jurnal Industri 1 (2): 13-21.

Ayu, Permatasari Y. 2013. Hubungan Tingkat Kebisingan dengan Gangguan Psikologis Pekerja di Bagian Weaving di PT. X Batang, Jawa Tengah. J Kesehat Masy Univ Diponegoro.

Azmi, AN. 2016. Hubungan Intensitas Suara Dengan Gangguan Pendengaran Pekerja Unit Kiln Pt . Holcim Indonesia Tbk . Cilacap Plant Tahun 2016. 2016;83-97.

Endroyo, B. 2006. Peranan Manajemen K3 Dalam Pencegahan Kecelakaan Kerja Konstruksi. Jurnal Teknik Sipil 3 (1): 23-30.

Heni, Y. 2011. Improving Our Safety Culture. Jakarta: PT. Gramedia Pustaka Utama.

Hidayati, N.F. Winarko. Tohari, I. 2014. The Factors Relating to Self Protection Tools on the Workers (Study in PT. Japfa Comfeed Indonesia Tbk, the Divition of Techniue and Production) 2014. Jurnal Kesehatan Masyarakat Unnes 12 (3): 26-33.

Ikhsani, A. 2019. Bahaya Potensial Fisik pada Proses Pengolahan Kelapa Sawit PT. Perkebunan Nusantara VII tahun 2019. Jurnal Kesehatan Masyarakat Vol. 10 No.2.

Infodatin Pusat Data dan Informasi Kementrian Kesehatan RI. 2019. Situasi Kesehatan Kerja.

Keputusan Menteri Kesehatan RI Nomor 1405/MENKES/SK/XI/2002 tentang Persyaratan Kesehatan Lingkungan Kerja Perkantoran dan Industri. Jakarta.

Keputusan Menteri Tenaga Kerja RI Nomor Kep.51/MEN.1999 tentang Nilai Ambang Batas Faktor Fisika di Tempat Kerja. Jakarta.

Kholik, HM. 2012. Analisis Tingkat Kebisingan Peralatan Produksi Terhadap Kinerja Karyawan. J Tek Ind.

Notoatmodjo, S. 2010. Ilmu Perilaku Kesehatan. Jakarta: Rineka Cipta.

Peraturan Menteri Kesehatan RI Nomor 70 Tahun 2016 tentang Standar dan Persyaratan Kesehatan Lingkungan Kerja Industri. Jakarta.

Silitonga, N. 2016. Hubungan Kebisingan dengan Pendengaran Pekerja. 2016;51(Hubungan kebisingan dengan pendengaran pekerja):1-7.

Solekhah, S.A. 2018. Faktor Perilaku Kepatuhan Penggunaan Apd Pada Pekerja PT X. Jurnal Promkes Vol. 6 No.1.

Suma'mur, PK. 2014. Higiene Perusahaan dan Kesehatan Kerja. Sagung Seto. Jakarta.

Utama, W. T. 2019. Pajanan Panas dengan Status Hidrasi Pekerja. Jurnal Kesehatan Unila Vol.3.No.2.

Wita, I.W. 2016. Cintailah Jantung Kita. Penerbit Balai Pustaka, Jakarta.

Wulandari, J. 2018. Efek Iklim Kerja Panas Pada Respon Fisiologis Tenaga Kerja Di Ruang Terbatas. Indones J Occup Saf Heal. 2018;6(2):207. 